\title{
PATHOGENIC VARIABILITY OF COMMON SCAB OF POTATO (STREPTOMYCES SCABIES) IN DISTRICT POONCH AJ\&K
}

Hafiz Matee-ur-Rehman', Muhammad Tariq-Khan', Basharat Mehmood ${ }^{1}$, Asma Bashir ${ }^{1}$, Muhammad Adnan Asghar ${ }^{2}$, Muhammad Usama ${ }^{3}$, Noreen Akhtar ${ }^{4}$, Muhammad Tahir Younas ${ }^{1}$

${ }^{1}$ Department of Plant Pathology, University of the Poonch, Rawalakot, Pakistan.

${ }^{2}$ Department of Entomology, University of the Poonch, Rawalakot, Pakistan.

${ }^{3}$ Department of Plant Pathology, PMAS-Arid Agriculture University Rawalpindi, Pakistan.

${ }^{4}$ Department of Entomology, PMAS-Arid Agriculture University Rawalpindi, Pakistan.

ART ICLE IN F O

\section{Article history \\ Received: $13^{\text {th }}$ May, 2019 \\ Revised: 29th July, 2019 \\ Accepted: 28 th August, 2019}

Keywords
Potato scab
Yield
Streptomyces scabies
Pathogenic variability

\section{A B S T R A C T}

(Solanum tuberosum L.) potato is globally an imperative crop. Various biotic constraints affect its yield production and market value. Streptomyces scabies is one of them which reduce the market value besides meet the requirements for the rhizomes. The affect findings were conducted to appraise the pathogenic variation, pathogenicity, morphological and biochemical depiction of Streptomyces species linked by potato tubers grown-up happening Poonch (district). Disease incidence index and variation in pathogenic data of disease be there is being cultivated by means of utilizing various inclusion in addition to the techniques of characterization. Test of Pathogenicity remained indicated that all insulates stayed pathogenic on all cultivar causing indications using assertiveness of straining to fluctuate starting slightly to discreetly function.

Corresponding Author: Hafiz Matee-ur-Rehman

Email: hafizmatee1@gmail.com

(C) 2019 EScience Press. All rights reserved.

\section{INTRODUCTION}

Potato (Solanum tuberosum L,) belongs to the Solanaceae family. Throughout the world, it is the $4^{\text {th }}$ most imperative yield. It originates commencing South America but now it is being cultivating all over the world (Ahmad et al., 2011). It is cultivated over an area of 19302642 ha with388190674 tonnes production around the world. In Pakistan, it is cultivated in an area of 183961 ha with 4142399 tonnes production (FAO, 2017). It contains about $1 \%$ vitamins, $2 \%$ protein, $18 \%$ starch, $79 \%$ water with the addition of many minerals and traces of elements. Many biotic and abiotic constraints affects the quality and quantity of potato of crop (Abbasi et al., 2012). Among all constraints Streptomyces Scabies is an important pathogen of potato crop (Hill and Lazarovits, 2005). S. Scabies belongs to family streptomycetacae. It is an important soil-borne filamentous bacteria pathogen which affects solanaceae family badly. Underground tissues of host plants highly infected by streptomycetacae saprophytic. S. Scabies seems as haphazardly disseminated surface in addition with bottomless rutted corky abrasions (lesions). These lesions are different in color and size but furthermost perhaps that these lesions have brown color with the diameter of few $\mathrm{mm}$ (Lerat et al., 2009). Regardless the significance of mutual covering, proficient techniques for the analysis of sickness are deficient. Potato is a valuable crop in Poonch district of Azad Jammu and Kashmir. Though, yield of tuber is 
usually extensive lesser as compared to northerly zones of Pakistan. It is due to different environmental conditions, but also biotic factors are included. These may be fungal, bacterial and viral pathogens. Common scab has been seen frequently in potato growing field of Poonch district during the routine survey of 2017. During the survey it has been observed that the pathogen does not only destroys the tubers of potato also reduce its value of market. No research in terms of systematics has been performed toward the discovery of definite image of incidence of disease in this zone, consequently the current reading stayed explore to determine pathogenic occurrence, variation, biological, physiological, structural characterization and occurrence of S. Scabies in potato growing areas of Poonch district and Azad Jammu and Kashmir.

\section{MATERIALS AND METHODS}

Survey and sampling: Survey was conducted in potato growing areas for the collection of scab samples from four different locations from district Poonch Azad Jammu Kashmir, Pakistan (Figure 1). Fifteen samples from each field were collected randomly.

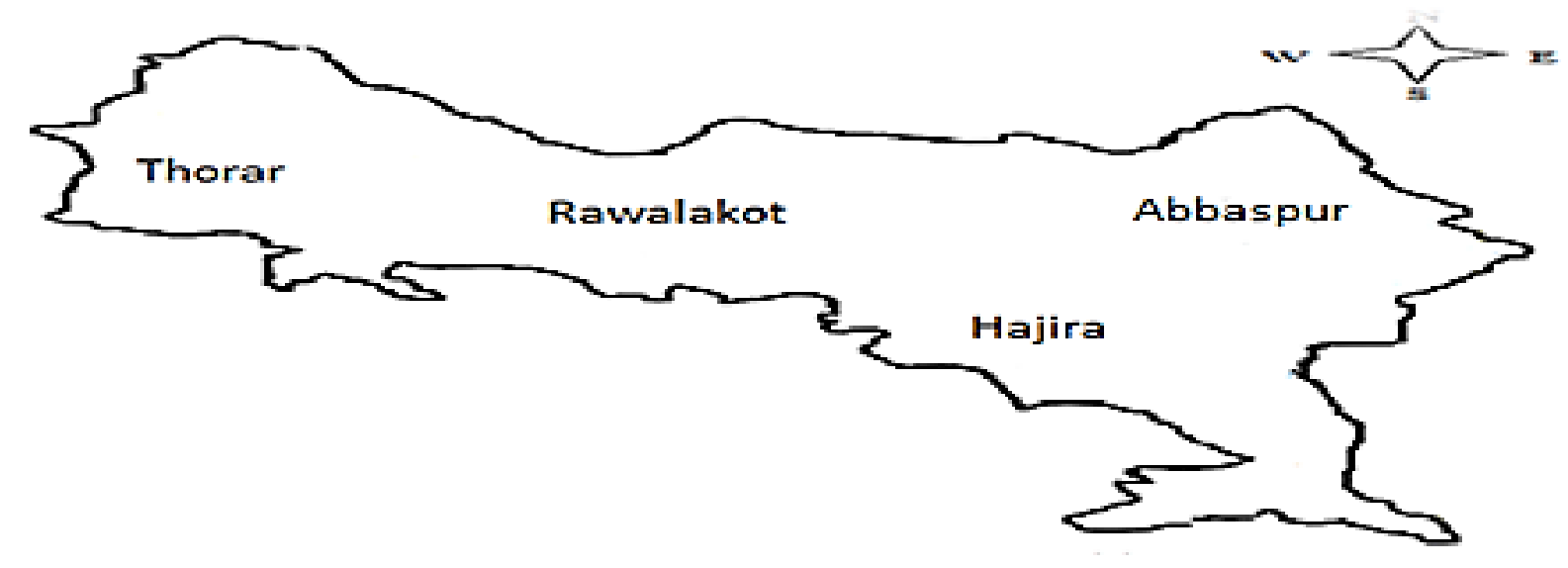

Figure 1. Sample collection sites of district Poonch.

Separation and sanitization of pathogen of bacteria: (NA) Nutrient agar media were intended for the separation of bacterial isolates. After incubation of 24-48 hours at $25 \pm 2{ }^{\circ} \mathrm{C}$ purification was done on water agar (WA) media by picking a single colony.

Pathogenicity of selected isolates: S. Scabies separated resulting blend remained used to $3 \times 10^{7} \mathrm{CFU} / \mathrm{ml}$ through Bencheikh and Setti (2007) procedure. Blend of potting was used for seedling of tubers like FYM, Sand, and clay (1:1:1) and sanitized using 37\% formalin (commercial). The licensed cultivar of the tubers of potato named Bartina well-known meant for the sensitivity concerning the communal scab stayed immunized and immersed now suspension of bacteria $\left(3 \times 10^{7} \mathrm{CFU} / \mathrm{ml}\right)$ in $50 \mathrm{ML}$ distill water. Immunized tubers of potato stayed protected using soil immediately. Each pot contains diameter of $15-\mathrm{cm}$.

Hypersensitive reaction: In the purified water, the separates of postponement were set with the adjustment to contain $3 \times 10^{7} \mathrm{CFU} / \mathrm{ml}$ of clusters of individually separate. Inoculum is there inserted keen on the biaxial flank of the Nicotiana tabacum L. (tobacco) foliage by means of a $1 \mathrm{~mL}$ hypodermal inject partaking $0.47 \mathrm{~mm}$ prickle. Inoculated florae stayed enclosed through bag of plastic meant for $24 \mathrm{hrs}$ to retain the high level of humidity. Afterward $24 \mathrm{hrs}$ the bags remained detached then floras stayed unprotected at $28{ }^{\circ} \mathrm{C}$ intended for exactly 36 hrs below dusky besides sunny circumstances (day $14 \mathrm{hrs}$, night $10 \mathrm{hrs}$ ). Plants in control treatment were stayed inoculated with purified water with the addition of interpretation in the same environment. After every $36 \mathrm{hrs}$ of inoculation, the observations were made. Pathogen identification: All the pathogenic isolates were identified on the bases of biochemical tests as described by Schaad (1998). All bacterial separates remained examined intended for staining of gram by using methodology described by Shirling and Gottlieb (1966). The test of potassium hydroxide (KOH) was just viewed as progressive when looping happened inside initial 30 seconds of blending the microbes in potassium hydroxide $(\mathrm{KOH})$ suspension. For the observation of sporulation, separates be there protected besides developed about a curved protection slide (coverslip) indirectly immunized in plates of media. The protection 
slides (coverslips) stayed detached afterward sporulation besides obeying mycelium, shape of cell, chains of spores and size remained detected but also for the effects of development of separates on media at several temperatures as 18,28 and $35^{\circ} \mathrm{C}$ was inspected.

Index of common scab: Scab (common) be there tested going on altogether Potato (Solanum tuberosum L,) intended for severity check in addition with the percentage of area concealed through abrasions (lesions). The check of severity was evaluated by using scale $0-5$ defined by Bjor and Roer (1980). Pathogenic variability between isolates was recorded by using common scab disease index (CSDI).

CSDI $\%=\frac{\text { (Number of tubers in each rating } \times \text { rating) }}{\text { Total No. of tubers }} \times 100$

Incidences of disease: Incidence of disease was considered commencing the individual field by using the formula:

$$
\text { Disease Incidence }=\frac{\text { No. of infected tubers }}{\text { Total No. of tubers }} \times 100
$$

\section{RESULTS AND DISCUSSIONS}

Disease incidence: It is noticeable that the maximum common scab's incidence (45.5\%) was seen in Rawalakot fields by keeping an eye on Hajira (39\%), Abbaspur (38.5\%) and the lowest. In Thorar fields disease incidence was $36 \%$ (Table 1 ).

Table 2. Mean Common Scab Disease Incidence in the area of district Poonch.

\begin{tabular}{lll}
\hline Sr. No. & Localities & Incidence of Disease (\%) \\
\hline 1 & Abbaspur & 38.5 \\
2 & Thorar & 36 \\
3 & Rawalakot & 45.5 \\
4 & Hajira & 39 \\
Mean Disease Incidence & 39.75 \\
\hline
\end{tabular}

Characterization of pathogen: Species of Streptomyces be there quarantined commencing potatoes by way of Lambert and Loria (1989). Characterization and further studies of isolates different biochemical tests applied. For this purpose 10 isolates AHU-1, AHU-2, BA-1, BA-2, CR-1, CR-2, DHL-1, DHL-2, ET-1 and ET-2 were selected. Isolates were identified by using ISP methodology (Shirling and Gottlieb, 1966), Biochemical, Physiological and Morphological characters exposed that, entirely separates were Gram +tive. Gram-positive bacteria mixed in solution of potassium hydroxide and no response occurred (absence of looping).

Each isolate observed under microscope at 100X discovered that cells were filamentous $\sim 0.7-1 \mu \mathrm{m}$ wide in addition with the size of the ordinary cell that was experienced was $10-100 \mu \mathrm{m}$, typical temperature that was mandatory as well as perceived for the growth of bacteria was $27 \pm 2^{\circ} \mathrm{C}$. Results were confidently responded positively. Such correspondence (similarity) recommends that these isolates (separates) which were acquired from the Poonch region are nearly associated with S. scabies (Table 2).

Pathogenicity: Bacterial isolates tested on Bartina cultivar and test give positive pathogenicity results. All treated potato tubers were shown Specific common scab symptoms on as paralleled by the control (non-treated) potato tuber have not at all any indications of scab (common). Statistically, significant differences among means of indexes common scab (disease) exposed through the isolates (segregates) of $S$. scabies was seen. Isolates from Rawalakot stayed seen furthermost virulent shadowed by CR-1, DHL-1, DHL-2, BA-I, BA-2, AHU-1, AHU2 , ET-2, and ET-1. Isolates (segregates) was dignified toward existing pathogens more pathogenic after 3 tubers out of 5 established symptoms of scab (King et al., 1991).

Table 3. Description of isolates of Streptomyces isolates biochemically

\begin{tabular}{lll}
\hline Sr. No. & Characteristics & Observed facts \\
\hline 1 & Growth & On NA media $(+)$ \\
2 & Gram staining & Cell counterstained $\left(\mathrm{G}^{+} \mathrm{VE}\right)$ \\
3 & Reaction of hypersensitivity & Response arise among 26-54 hours on plants of tobacco $(+)$ \\
4 & Cell size & Average size at 60Xmagnification \\
5 & Pathogenicity & Disease symptoms appears $(+)$ \\
6 & Color of colony & Smooth $(+)$, shiny and yellow \\
7 & Cell shape & Filamentous, Off white with $0.7-2.0 \mu \mathrm{m}$ in diameter \\
8 & Growth temp. & Average temperature $25 \pm 2^{\circ} \mathrm{C}$ \\
9 & Spore mass color & Gray \\
10 & Reverse mycelium color & Brown
\end{tabular}




\begin{tabular}{lll}
11 & Spore chain morphology & Espiral \\
\hline 12 & L-Arabinose, & + \\
13 & D-Fructose & + \\
14 & D-Glucose & + \\
15 & Raffinose & + \\
16 & Sucrose & + \\
17 & D-Xylose & + \\
18 & I-Inositol & + \\
\hline
\end{tabular}

Pathogenicity: Bacterial isolates tested on Bartina cultivar and test give positive pathogenicity results. All treated potato tubers were shown Specific common scab symptoms on as paralleled by the control (non-treated) potato tuber have not at all any indications of scab (common). Statistically, significant differences among means of indexes common scab (disease) exposed through the isolates (segregates) of $S$. scabies was seen. Isolates from Rawalakot stayed seen furthermost virulent shadowed by CR-1, DHL-1, DHL-2, BA-I, BA-2, AHU-1, AHU-2, ET-2, and ET-1. Isolates (segregates) (Figure 2) was dignified toward existing pathogens more pathogenic after 3 tubers out of 5 established symptoms of scab (King et al., 1991).

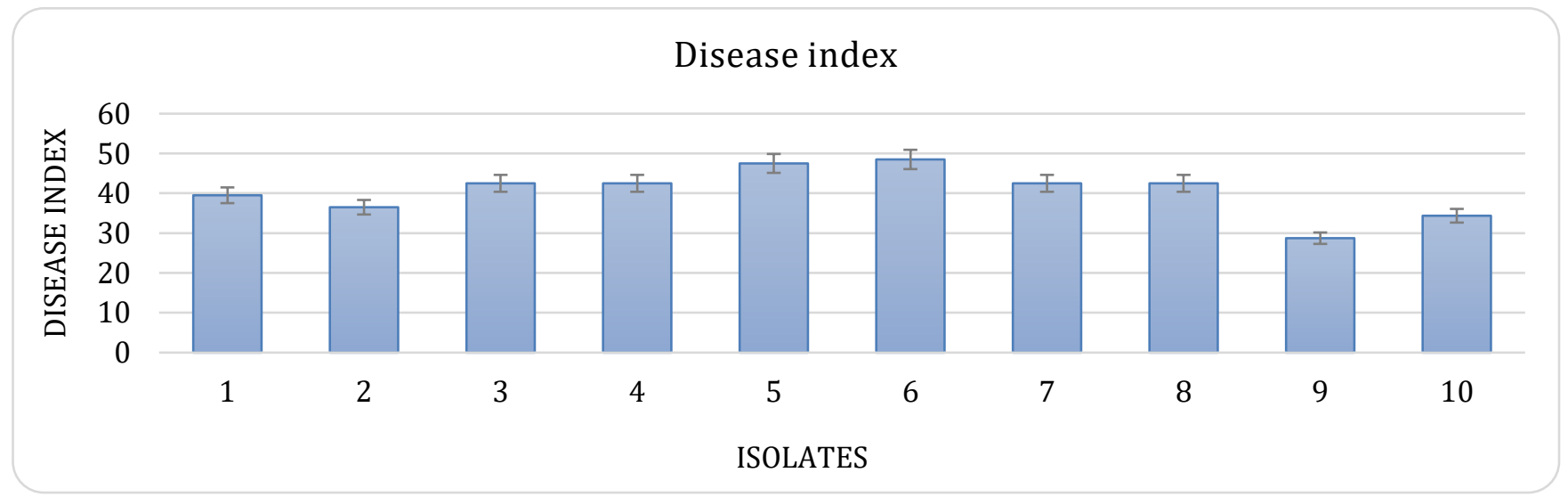

Figure 2. Streptomyces scabies isolates showing the index of common scab disease.

we have studied the strains of (Solanum tuberosum L.) potato scab pathogen from genus Streptomyces on the base of biochemical, morphology, and physiological, configurations. In our incident, entirely the isolates (segregates) got through altered zones of district Poonch be there approximately matching in their morphological and physiological characters. Actually, diverse tests of laboratory standards such as color of colony, shape of cell, color of mass spore, chains of spores, morphological characters and color of Gram exist comparable towards streptomyces. Intended for test of pathogenicity, the signs encouraged through our isolates (segregates) stood same in the way of that triggered through the locus strain. Thus, this comparison tells us that the isolates formed by the Poonch zone are nearly linked to Streptomyces scabies.

Author contributions: Hafiz Matee-ur-Rehman and Muhammad Tariq-Khan designed the studies, executed the experiments and collected data and all the authors contributed in edited the manuscript.

Conflict of interest: The authors declare no conflict of interest.

\section{REFERENCES}

Abbasi, N.A., Zahoor, M., Khan, H., Qureshi, A.A., 2012. Effect of encapsulated calcium carbide application at different growth stages on potato (Solanum tuberosum L.) growth, yield and tuber quality. Pakistan Journal of Botany 44, 1543-1550.

Ahmad, N., Khan, M.A., Khan, N.A., Binyamin, R., Khan, M.A., 2011. Identification of resistance source in potato germplasm against PVX and PVY. Pakistan Journal of Botany 43, 2745-2749.

Bencheikh, M., Setti, B., 2007. Characterization of Streptomyces scabies isolated from common scab lesions on potato tubers by morphological, biochemical and pathogenicity tests in Chlef region 
in western Algeria. Sciences and Technologie. C, Biotechnologies, pp. 61-67.

Bjor, T., Roer, L., 1980. Testing the resistance of potato varieties to common scab. Potato Research 23, 3347.

FAO, 2017. Economic Survey of Pakistan, 2016-17, Finacae division Economic advisor's wing. Food and Agriculture Organization, Islamabad, pp. 21-22.

Hill, J., Lazarovits, G., 2005. A mail survey of growers to estimate potato common scab prevalence and economic loss in Canada. Canadian Journal of Plant Pathology 27, 46-52.

King, R.R., Lawrence, C.H., Clark, M.C., 1991. Correlation of phytotoxin production with pathogenicity ofStreptomyces scabies isolates from scab infected potato tubers. American Potato Journal 68, 675-
680.

Lambert, D.H., Loria, R., 1989. Streptomyces scabies sp. nov., nom. rev. International Journal of Systematic Bacteriology 39, 387-392.

Lerat, S., Simao-Beaunoir, A.-M., Beaulieu, C., 2009. Genetic and physiological determinants of Streptomyces scabies pathogenicity. Molecular Plant Pathology 10, 579-585.

Schaad, N.W., Jones, J.B., Chun, W., 2001. Laboratory Guide for the Identification of Plant Pathogenic Bacteria. American Phytopathological Society, New York, USA.

Shirling, E.B., Gottlieb, D., 1966. Methods for characterization of Streptomyces species. International Journal of Systematic Bacteriology $16,313-340$. 